\title{
Thematic series - Low back pain
}

\author{
Dino Samartzis ${ }^{1^{*}}$ and Theodoros B. Grivas ${ }^{2^{*}}$
}

Keywords: Spine, Low back pain, Risk factors, Prevention, Diagnosis, Treatment, Outcome, Disc Degeneration

Low back pain is the world's most disabling condition, involving all populations and crossing all boundaries $[1,2]$. Such pain leads to tremendous socioeconomic and healthcare consequences. In the United States alone, the direct and indirect costs associated with low back pain surpass 90 billion USD per year, with similar adjusted rates in different countries [3]. Low back pain is the second condition following the common cold that motivates individuals to seek medical consultation, and is the top debilitating condition in individuals over the age of 45 [4-7]. Such a condition can lead to diminished quality of life, decreased activity, loss of wages, and psychological distress [4-7]. In fact, chronic low back pain may even age the brain faster and destroy critical brain tissue in comparison to asymptomatic individuals [8].

Throughout the years, various conservative and nonconservative measures have been developed to treat low back pain [5]. However, the outcome of such treatment is often not predictable or satisfactory [6]. Furthermore, the use of opioid consumption to manage low back pain has escalated in recent years, prompting concern of its use and abuse $[9,10]$. As such, identifying risk factors that assist in preventing low back pain as well as predicting outcomes from various management options has taken center-stage. Large-scale epidemiological and patient cohorts (i.e. "big data" platforms) have been developed that aim to have a better understanding of imaging, clinical and "omics" profiles towards understanding risk/prediction and susceptibility to low back pain and its severity [11-20]. Novel treatments are being pursued worldwide to target potential pain generating sources in hopes to treat such pain and improve patient outcomes and quality of life. Animal models of pain have been and are currently being developed to address the pathogenesis of pain, understand pain pathways and mechanisms,

\footnotetext{
* Correspondence: dsamartzis@msn.com; tgri69@otenet.gr

${ }^{1}$ Department of Orthopaedics and Traumatology, The University of Hong Kong, Pokfulam, Hong Kong, SAR, China

2Orthopaedics and Trauma Department, "Tzaneio" General Hospital of Piraeus, Piraeus 18536, Greece
}

and facilitate therapeutic drug discovery and testing $[21,22]$. The role of abnormal biomechanics, occupational, lifestyle and psychosocial exposures have been and continue to be addressed to enhance understanding of the causes and consequences of low back pain [11, 12, 17, 18, 23-30]. In short, the implications of low back pain to patients as well as to clinicians and researchers alike are substantial, and will continue to be of importance.

Due to the gravity that low back pain imposes upon society, and its implications upon clinical management, health-care costs, and various research platforms, the Scoliosis and Spinal Disorders journal has initiated a "Low Back Pain" thematic series. The journal will welcome all types of articles and research designs, with the exception of case reports, that focus on low back pain. We believe this series will broaden the understanding of low back pain, and provide new insights into prevention, refined diagnoses, management options, novel therapeutics and outcomes.

\section{Authors' contributions}

DS drafted the manuscript. DS and TG provided critical comments and final review of the manuscript. The authors read and approved the final manuscript.

\section{Competing interests}

The authors declare that they have no competing interests.

\section{Disclosure}

The authors have nothing to disclose in relation to this work.

Received: 12 December 2016 Accepted: 21 December 2016 Published online: 18 January 2017

\section{References}

1. DALYs GBD, Collaborators H, Murray CJ, Barber RM, Foreman KJ, Abbasoglu Ozgoren A, et al. Global, regional, and national disability-adjusted life years (DALYs) for 306 diseases and injuries and healthy life expectancy (HALE) for 188 countries, 1990-2013: quantifying the epidemiological transition. Lancet. 2015;386:2145-91.

2. Vos T, Flaxman AD, Naghavi M, Lozano R, Michaud C, Ezzati M, et al. Years lived with disability (YLDs) for 1160 sequelae of 289 diseases and injuries 1990-2010: a systematic analysis for the Global Burden of Disease Study 2010. Lancet. 2012;380:2163-96.

3. Dagenais S, Caro J, Haldeman S. A systematic review of low back pain cost of illness studies in the United States and internationally. Spine J. 2008;8:8-20. 
4. Fourney DR, Andersson GBJ, Arnold PM, Dettori J, Cahana A, Fehlings MG, et al. Chronic low back pain: a heterogeneous condition with challenges for an evidence-based approach. Spine. 2011;36:S1-9.

5. Karppinen J, Shen FH, Luk KDK, Andersson GBJ, Cheung KMC, Samartzis D. Management of degenerative disc disease and chronic low back pain Orthop Clin North Am. 2011:42:513-28.

6. Shen FH, Samartzis D, Andersson GBJ. Nonoperative management of acute and chronic low back pain. J Am Acad Ortho Surg. 2006;14:477-87.

7. Wong A, Samartzis D. Low back pain in older adults - the need for specific outcome and psychometric tools. J Pain Res. 2016;8:989-91.

8. Apkarian AV, Sosa Y, Sonty S, Levy RM, Harden RN, Parrish TB, et al. Chronic back pain is associated with decreased prefrontal and thalamic gray matter density. J Neurosci. 2004;24:10410-5.

9. Abdel Shaheed C, Maher CG, Williams KA, Day R, McLachlan AJ. Efficacy, tolerability, and dose-dependent effects of opioid analgesics for Low back pain: a systematic review and meta-analysis. JAMA Intern Med. 2016; 176:958-68.

10. Ballantyne JC. Avoiding opioid analgesics for treatment of chronic Low back pain. JAMA. 2016:315:2459-60.

11. Samartzis D, Karppinen J, Chan D, Luk KDK, Cheung KMC. The association of lumbar intervertebral disc degeneration on MRI in overweight and obese adults: a population-based study. Arthr Rheum. 2012;64:1488-96.

12. Samartzis D, Karppinen J, Mok F, Fong DYT, Luk KDK, Cheung KMC. A population-based study of juvenile disc degeneration and its association with overweight and obesity, low back pain, and diminished functional status. J Bone Joint Surg Am. 2011;93:662-70.

13. Samartzis D, Borthakur A, Belfer I, Bow CH, Lotz JC, Wang H-Q, et al. Novel diagnostic and therapeutic methods for intervertebral disc degeneration and low back pain. Spine J. 2015;15:1919-32.

14. Williams FM, Sambrook PN. Neck and back pain and intervertebral disc degeneration: role of occupational factors. Best Pract Res Clin Rheumatol. 2011;25:69-79.

15. Williams FM, Spector TD, MacGregor AJ. Pain reporting at different body sites is explained by a single underlying genetic factor. Rheumatology (Oxford). 2010;49:1753-5.

16. Maatta J, Karppinen J, Paananen M, Bow C, Luk KDK, Cheung KMC, et al. Refined phenotyping of Modic changes: potential imaging biomarkers of prolonged severe low back pain and disability. Medicine. 2016:95:e3495.

17. Mikkonen P, Heikkala E, Paananen M, Remes J, Taimela S, Auvinen J, et al. Accumulation of psychosocial and lifestyle factors and risk of low back pain in adolescence: a cohort study. Eur Spine J. 2016;25:635-42.

18. Mikkonen PH, Laitinen J, Remes J, Tammelin T, Taimela S, Kaikkonen K, et al. Association between overweight and low back pain: a population-based prospective cohort study of adolescents. Spine (Phila Pa 1976). 2013;38:1026-33.

19. Livshits G, Popham M, Malkin I, Sambrook PN, Macgregor AJ, Spector T, et al. Lumbar disc degeneration and genetic factors are the main risk factors for low back pain in women: the UK Twin Spine Study. Ann Rheum Dis. 2011;70:1740-5.

20. Crawford RJ, Volken T, Valentin S, Melloh M, Elliott JM. Rate of lumbar paravertebral muscle fat infiltration versus spinal degeneration in asymptomatic populations: an age-aggregated cross-sectional simulation study. Scoliosis Spinal Disord. 2016;11:21.

21. Kim JS, Ahmadinia K, Li X, Hamilton JL, Andrews S, Haralampus CA, et al. Development of an experimental animal model for lower back pain by percutaneous injury-induced lumbar facet joint osteoarthritis. J Cell Physiol. 2015;230:2837-47.

22. Millecamps M, Czerminski JT, Mathieu AP, Stone LS. Behavioral signs of axial low back pain and motor impairment correlate with the severity of intervertebral disc degeneration in a mouse model. Spine J. 2015:15:2524-37.

23. Jussila L, Paananen M, Nayha S, Taimela S, Tammelin T, Auvinen J, et al. Psychosocial and lifestyle correlates of musculoskeletal pain patterns in adolescence: a 2-year follow-up study. Eur J Pain. 2014;18:139-46.

24. Samartzis D, Cheung J, Karppinen J, Lotz JC. Disc degeneration and low back pain: are they "fat" related conditions? Global Spine J. 2013;3:133-43.

25. Davydov DM, Perlo S. Cardiovascular activity and chronic pain severity. Physiol Behav. 2015;152:203-16.

26. Lallukka T, Viikari-Juntura E, Viikari J, Kahonen M, Lehtimaki T, Raitakari OT, et al. Early work-related physical exposures and low back pain in midlife: the Cardiovascular Risk in Young Finns Study. Occup Environ Med 2016.
27. Von Forell G, Stephens TK, Samartzis D, Bowden AE. Low back pain: A biomechanical rationale based on "patterns" of disc degeneration. Spine 2015; [Epub ahead of print]:

28. latridis JC, Kang J, Kandel R, Risbud MV. New horizons in spine research: disc biology, spine biomechanics and pathomechanisms of back pain. J Orthop Res. 2016;34:1287-8.

29. Adams MA. Biomechanics of back pain. Acupunct Med. 2004;22:178-88.

30. Balague F, Pellise F. Adolescent idiopathic scoliosis and back pain. Scoliosis Spinal Disord. 2016:11:27.

\section{Submit your next manuscript to BioMed Central and we will help you at every step:}

- We accept pre-submission inquiries

- Our selector tool helps you to find the most relevant journal

- We provide round the clock customer support

- Convenient online submission

- Thorough peer review

- Inclusion in PubMed and all major indexing services

- Maximum visibility for your research

Submit your manuscript at www.biomedcentral.com/submit 